\title{
Analisis Kinerja Keuangan pada Industri Tempe di Nagori Rambung Merah Kabupaten Simalungun
}

\author{
Sumaizar \\ Sekolah Tinggi Akuntansi dan Manajemen Indonesia \\ sumaizar@gmail.com
}

\author{
Muhammad Rido \\ Sekolah Tinggi Akuntansi dan Manajemen Indonesia \\ dhoez588@gmail.com
}

\author{
Eko Deswin Miechaels Siringo-Ringo \\ Sekolah Tinggi Akuntansi dan Manajemen Indonesia \\ ekodeswin10@yahoo.com
}

\begin{abstract}
This study aims to determine the financial performance of the tempe industri in Nagori Rambung Merah. To measure financial performance, an analysis tool called financial ratio analysis can be used. In carrying out this analysis, it is necessary to calculate financial ratios that include certain aspects. Financial statement analysis will give the best results when used in a combination to show changes in financial condition or operating performance over a given period. The data analysis method used is descriptive analysis and the data is presented in the form of balance sheet financial statements and income statements. This data processing uses the Microsoft Excel software package followed by financial ratio analysis by looking at the comparison of financial ratios, namely the ratio of liquidity, solvability, and profitability. In this way, it will be obtained the results of the analysis of the correct financial performance for the tempe industri in Nagori Rambung Merah.
\end{abstract}

Keywords : The ratio of liquidity, solvability, proftability, financial ratios.

\section{PENDAHULUAN}

Untuk mengetahui sehat tidaknya suatu usaha biasanya dapat dilihat dari keadaan fisik perusahaan seperti sarana dan prasarana yang mendukung usaha, unsur keuangan perusahaan untuk dapat mengevaluasi apakah kebijakan yang ditempuh sudah tepat atau belum untuk menghindari kebangkrutan perusahaan karena faktor keuangan yang tidak sehat. Saat ini, banyak industri kecil tidak memperhatikan faktor kesehatan keuangan dalam usahanya hal inilah yang sering menjadi pemicu kebangkrutan usaha industri tersebut. Untuk menghindari kebangkrutan tersebut maka pemilik usaha selalu berusaha agar usahanya tetap hidup dengan selalu memperhatikan dan mengadakan evaluasi terhadap perkembangan usahanya dari waktu ke waktu.
Pemilik juga harus dapat memahami kinerja keuangan usahanya karena kinerja keuangan tersebut akan mempengaruhi kelangsungan hidup usaha yang telah dijalankan. Faktor yang harus diperhatikan untuk mengetahui kinerja keuangan adalah laporan keuangan perusahaan yang terdiri dari Neraca, Laporan Laba Rugi dan laporan keuangan lainnya. Untuk mengukur kinerja keuangan dapat digunakan alat analisis yang disebut analisis rasio keuangan. Untuk melakukan analisis ini diperlukan perhitungan rasio-rasio yang mencantumkan aspek-aspek tertentu. Analisis laporan keuangan akan memberikan hasil terbaik jika digunakan dalam suatu kombinasi untuk menunjukkan perubahan kondisi keuangan atau kinerja operasional perusahaan. Analisis rasio dapat memberikan penilaian terhadap kinerja 
keuangan suatu usaha. Dalam hal ini usaha yang dimaksud adalah usaha Tempe Cempaka yang terletak di Jalan Cempaka Atas Huta I Nagori Rambung Merah Kecamatan Siantar Kabupaten Simalungun yang merupakan salah satu dari sekian banyak Industri Tempe yang ada di Kecamatan Siantar. Usaha ini telah berproduksi selama 20 tahun serta memiliki rasa yang enak. [1] menyatakan adapun untuk rasa tempe yang normal adalah tidak terdapat rasa selain rasa tempe. Usaha ini memiliki potensi untuk terus dipertahankan, karena pangsa pasar industri tempe yang luas dan permintaan terhadap produksi ini cukup banyak dari luar daerah. Namun agar industri tempe ini lebih baik lagi perlu dilakukan analisis keuangan usaha untuk menilai kinerja keuangan terhadap industri tempe ini.

Namun setelah dilakukan pengamatan bahwa industri ini belum memiliki laporan keuangan tersendiri untuk menilai kinerja keuangan usaha yang telah dijalankan. Hal ini disebabkan kurangnya pengetahuan dan kemampuan pemilik dalam membuat laporan keuangan sehingga industri tempe ini sulit diketahui kinerja keuangannya. Berdasarkan latar belakang tersebut hal yang menjadi rumusan masalah adalah "Bagaimana kinerja keuangan yang ada di Industri Tempe Cempaka?"

Penelitian ini bertujuan untuk mengetahui perkembangan kinerja keuangan usaha Tempe Cempaka dilihat dari rasio likuiditas, rasio solvabilitas dan rasio profitabilitas. Manfaat penelitian ini bagi penulis untuk dapat mengetahui kinerja keuangan suatu perusahaan yang dilihat dari tingkat likuiditas, solvabilitas dan profitabilitas. Bagi pemilik usaha diharapkan menjadi bahan masukan untuk menganalisis keuangan usahanya.

\section{METODE PENELITIAN}

Penelitian ini dilaksanakan selama 1 minggu bulan Desember 2020. Tempat penelitian dilaksanakan di Huta I Nagori Rambung Merah Kecamatan Siantar Kabupaten Simalungun Data yang digunakan pada penelitian ini adalah data primer yang diperoleh dari Industri Tempe Cempaka yaitu data keuangan pada periode 2018 dan 2019. Pengumpulan data dilakukan dengan cara wawancara langsung kepada pemilik usaha tersebut. Analisis yang digunakan adalah analisis deskriptif dan data yang disajikan dalam bentuk laporan keuangan neraca dan laporan laba rugi. [2] menyatakan bahwa laporan keuangan menggambarkan kondisi keuangan dan hasil usaha suatu perusahaan pada saat tertentu atau jangka waktu tertentu. [3] menyebutkan laporan keuangan adalah hasil dari proses akuntansi yang digunakan sebagai alat untuk berkomunikasi antara data keuangan atau aktivitas perusahaan dengan pihak yang berkepentingan terhadap data atau aktivitas perusahaan. Pengolahan data ini menggunakan paket perangkat lunak Microsoft Excel dilanjutkan dengan analisis rasio keuangan dengan cara melihat perbandingan dari rasiorasio keuangan yaitu rasio likuiditas, solvabilitas, dan profitabilitas.

1) Rasio likuiditas merupakan rasio yang menggambarkan kemampuan perusahaan dalam memenuhi kewajiban lancarnya. Rasio ini dibagi 2 yaitu :

(a) Rasio lancar (current ratio) yaitu untuk mengukur kemampuan suatu perusahaan untuk memenuhi kewajiban jangka pendek melalui aktiva lancar yang dimilikinya.

Rumus :

$$
\text { Current Ratio }=\frac{\text { Aktiva Lancar }}{\text { Hutang Lancar }} \times 1 \text { kali }
$$

Kriteria :

$\mathrm{CR} \geq 2$, dinyatakan baik.

CR $<2-1,75$ dinyatakan cukup baik

CR $<1,75-1,5$ dinyatakan kurang baik.

CR $<1,5-1,25$ dinyatakan tidak baik.

$\mathrm{CR}<1,25$ dinyatakan sangat tidak baik.

(b) Rasio cepat (Quick ratio) menunjukkan kemampuan perusahaan untuk membayar utang lancar dengan aktiva lancar tanpa memperhitungkan nilai persediaan (inventory) 
Rumus :

Quick Ratio $=\frac{\text { Aktiva Lancar }- \text { Persediaan }}{\text { Hutang Lancar }} \times 1$ kali

Kriteria :

$\mathrm{QR} \geq 1,5$, dinyatakan baik.

$\mathrm{QR}<1,5-1,25$ dinyatakan cukup baik.

$\mathrm{QR}<1,25-1$ dinyatakan tidak baik.

$\mathrm{QR}<1$ dinyatakan sangat tidak baik.

2) Rasio Solvabilitas

Atau sering disebut Leverage ratio dimana untuk mengukur sejauh mana aktiva perusahaan dibiayai dengan utang.

Rumus :

Debt Ratio $=\frac{\text { Jumlah Hutang }}{\text { Jumlah Aktiva }} \times 100 \%$

Kriteria :

Debt Ratio $\leq 35 \%$ dinyatakan baik.

Debt Ratio > 35\% - 50\% dinyatakan cukup baik.

Debt Ratio > 50\% - 60\% dinyatakan kurang baik.

Debt Ratio > 60\% - 80\% dinyatakan tidak baik.

Debt Ratio > 80\% dinyatakan sangat tidak baik.

3) Rasio Profitabilitas

yaitu untuk menilai kemampuan perusahaan dalam mencari keuntungan. Jenis rasio yang digunakan adalah :

(a) Gross Profit Margin (GPE) yaitu persentase laba kotor dibandingkan dengan hasil penjualan. Semakin besar gross profit margin akan semakin baik keadaan operasi pada perusahaan. Rumus :

$G P M=\frac{\text { Laba Kotor }}{\text { Hasil Penjualan }} \times 100 \%$

Kriteria :

GPM $>20 \%$, dinyatakan baik.

GPM $<20 \%-10 \%$, dinyatakan cukup baik.

GPM $<10 \%-5 \%$, dinyatakan kurang baik.

GPM $<5 \%-1 \%$, dinyatakan tidak baik.

GPM $<1 \%$, dinyatakan sangat tidak baik. (b) Net Profit Margin (NPM) ialah mengukur laba bersih terhadap penjualan. Semakin tinggi net profit margin tersebut maka semakin baik operasi suatu perusahaan. Rumus :

$$
N P M=\frac{\text { Laba Bersih }}{\text { Hasil Penjualan }} \times 100 \%
$$

Kriteria :

NPM $>15 \%$, dinyatakan baik.

NPM $<15 \%-10 \%$, dinyatakan cukup baik.

NPM $<10 \%$ - 5\% dinyatakan kurang baik.

NPM $<5 \%-1 \%$ dinyatakan tidak baik.

NPM $<1 \%$, dinyatakan sangat tidak baik.

(c) Return on Investment (ROI) ialah rasio yang mengukur kemampuan perusahaan secara keseluruhan didalam menghasilkan suatu keuntungan dengan jumlah keseluruhan aktiva yang tersedia didalam suatu perusahaan [4]. Semakin tinggi rasio tersebut akan semakin baik keadaan pada suatu perusahaan.

Rumus :

$$
R O I=(\text { Laba Bersih } / \text { Total Aktiva }) \times 100 \%
$$

Kriteria :

$\mathrm{ROI} \geq 10 \%$, dinyatakan baik.

ROI $<10 \%-7 \%$, dinyatakan cukup baik.

ROI $<7 \%$ - $3 \%$, dinyatakan kurang baik.

ROI $<3 \%-1 \%$, dinyatakan tidak baik.

ROI $<1 \%$, dinyatakan sangat tidak baik.

(d) Retun on Equity (ROE) ialah rasio yang memperlihatkan sejauh manakah perusahaan tersebut mengelola modal sendiri (net worth) dengan secara efektif, mengukur tingkat keuntungan dari investasi yang telah dilakukan pemilik modal sendiri.

Rumus :

$$
\text { ROE }=(\text { Laba Bersih } / \text { Modal }) \times 100 \%
$$

Kriteria :

ROE $\geq 20 \%$, dinyatakan baik.

ROE $<20 \%-10 \%$, dinyatakan cukup baik.

ROE $<10 \%-5 \%$, dinyatakan kurang baik.

ROE $<5 \%-1 \%$, dinyatakan tidak baik.

ROE $<1 \%$, dinyatakan sangat tidak baik 


\section{HASIL DAN PEMBAHASAN \\ 3.1.Deskripsi Umum Industri Tempe Cempaka. \\ Industri tempe Cempaka adalah salah satu} usaha pengolahan kedelai menjadi makanan setengah jadi dalam bentuk tempe. Usaha ini merupakan usaha perorangan yang dikelola oleh Bapak Ribut Wahidi Sejak tahun 2000, berlokasi di Jl. Cempaka Atas Huta I Nagori Rambung Merah Kec. Siantar Kabupaten Simalungun. Usaha ini berproduksi setiap hari, karena melihat permintaan produk yang selalu ada setiap harinya. Tenaga kerja yang digunakan adalah tenaga kerja keluarga dan bahan baku yang digunakan adalah kedelai lokal. Adapun proses produksi tempe yaitu :

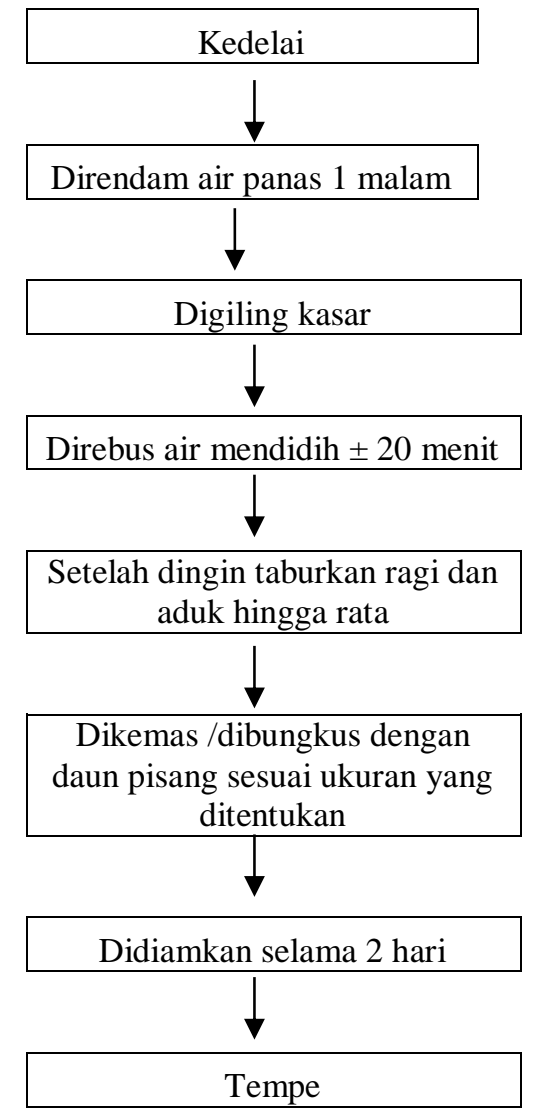

Gambar : Proses Produksi Tempe

Usaha tempe ini dalam memasarkan tempenya menggunakan kenderaan pribadi minibus. Hasil produksi dipasarkan di pasar Horas Pematangsiantar dan terkadang ada juga konsumen yang langsung datang ke pabrik untuk membeli langsung. Untuk memasarkan produk ini dimulai pukul 05.00 WIB - 10.00 WIB.

\subsection{Modal Usaha Tempe Cempaka.}

Modal merupakan hak yang dimiliki oleh perusahaan.Modal yang digunakan untuk usaha ini terdiri dari modal tetap dan modal tidak tetap. Modal tetap berupa peralatan yang digunakan untuk memproduksi tempe dan kenderaan minibus untuk memasarkan tempe, sedangkan modal tidak tetap berupa bahan baku dan bahan penolong dalam memproduksi tempe.

Tabel 1 : Jenis dan Nilai Modal Tetap

\begin{tabular}{|l|c|r|}
\hline \multicolumn{1}{|c|}{ Peralatan } & Unit & $\begin{array}{c}\text { Harga Beli } \\
\text { (Rp) }\end{array}$ \\
\hline Mesin Diesel & 1 & 2.000 .000 \\
\hline Mesin Penggiling & 1 & 1.500 .000 \\
\hline Pompa air & 1 & 1.500 .000 \\
\hline Ember & 10 & 500.000 \\
\hline Saringan & 2 & 250.000 \\
\hline Keranjang & 10 & 200.000 \\
\hline Tong perebusan & 1 & 500.000 \\
\hline Pisau & 10 & 100.000 \\
\hline Genset & 1 & 3.000 .000 \\
\hline Kenderaan & 1 & 80.000 .000 \\
\hline Total & & 89.550 .000 \\
\hline
\end{tabular}

Sumber : Data Primer (diolah)

\subsection{Volume Produksi, Harga Produk dan Hasil Penjualan.}

Produksi merupakan kegiatan inti dari usaha ini, dimana dalam memproduksi tempe untuk $1 \mathrm{Kg}$ kedelai setelah diolah dapat menghasilkan 15 bungkus tempe untuk harga jual Rp. 2.000 per bungkusnya. Dan 30 bungkus dengan harga jual Rp. 1.000 / bungkus dalam 1 $\mathrm{kg}$ kedelai yang diolah. Dan untuk rata-rata hasil produksi yang dijual setiap harinya berkisar $25 \mathrm{~kg}$ kedelai atau berkisar 750 bungkus tempe ukuran kecil / hari. Dan biasanya dari produksi tempe 750 bungkus tersebut hampir seluruhnya habis terjual setiap hari dan kalaupun lagi sepi hanya bersisa 
sekitar 1 keranjang yang berisikan 50 bungkus tempe.

Tabel 2 : Rekapitulasi Hasil Penjualan Tahun 2018 dan 2019

\begin{tabular}{|l|c|c|}
\hline Produk & $\mathbf{2 0 1 8}$ & $\mathbf{2 0 1 9}$ \\
\hline Tempe & Rp. 269.850.000 & Rp.269.750.000 \\
\hline
\end{tabular}

\subsection{Biaya-biaya Usaha Tempe Cempaka} a. Biaya bahan baku dan Bahan Penolong Pengusaha Tempe Cempaka dalam 1 kali produsi menggunakan kedelai $25 \mathrm{~kg} / \mathrm{hari}$. Berarti pembelian kedelai dalam setahun sebanyak $9.000 \mathrm{~kg} /$ tahun atau sekitar 9 ton tahun 2019 dengan biaya yang dikeluarkan berkisar Rp.95.000.000 tahun 2019 biaya ini meningkat dibanding dengan tahun 2018 berkisar Rp. 90.000.000 tahun 2018 .

Sedangkan bahan penolong yang digunakan dalam proses pembuatan tempe adalah kayu bakar, ragi dan tepung tempe. Kayu digunakan dalam proses pemasakan sebagai bahan bakar. Dalam pembelian kayu per karung dihargai Rp. 10.000 dan dalam 1 hari menghabiskan 3 karung kayu. Ragi dan tepung tempe digunakan untuk campuran dalam membuat tempe. Pembelian untuk $1 \mathrm{Kg}$ ragi yaitu Rp. 15.000 dipakai dipakai selama 1 bulan dan tepung dalam 1 kali proses Rp. 15.000 / kg. sebagai bahan bakar mesin penggiling digunakan solar sebanyak 10 liter/minggu dengan harga 8.000/liter dan oli untuk pelumas mesin 1 liter untuk 1 bulan dengan harga Rp. 30.000. Dalam setahun biaya pembelian bahan penolong yang dikeluarkan sebanyak 17.124.000 tahun 2019 dibandingkan dengan tahun 2018 berkisar Rp. 15.550.000. Minyak dan protein kedelai juga banyak dimanfaatkan untuk tujuan industri. [5]

\section{b. Biaya Overhead Pabrik}

- Biaya Listrik dan Telepon

Biaya listrik untuk pabrik tempe ditetapkan setiap bulan berkisar Rp. 150.000 karena untuk biaya listrik ini digabungkan ke rumah pemilik. Dan biaya telepon untuk pembelian pulsa ditetapkan Rp. 100.000 ribu dimana biaya tersebut digunakan untuk proses produksi sampai ke pemasaran tempe.
- Biaya penyusutan peralatan dan kenderaan. Peralatan yang digunakan dalam proses produksi akan mengalami penyusutan seiring dengan lamanya penggunaannya dan kenderaan yang digunakan untuk memasarkan tempe. Jumlah penyusutan peralatan dan kenderaan dalam setahun dapat dilihat dalam Tabel berikut:

Tabel 3 : Biaya Overhead Pabrik Tempe Cempaka

\begin{tabular}{|l|l|l|}
\hline By Overhead Pabrik & $\begin{array}{l}\text { Biaya (Rp) } \\
\mathbf{2 0 1 8}\end{array}$ & $\begin{array}{l}\text { Biaya (Rp) } \\
\mathbf{2 0 1 9}\end{array}$ \\
\hline Biaya Listrik & 1.800 .000 & 1.800 .000 \\
\hline Biaya Telepon & 1.200 .000 & 1.200 .000 \\
\hline Biaya penyusutan peralatan & 1.200 .000 & 1.200 .000 \\
\hline Biaya penyusutan kenderaan & 5.000 .000 & 5.000 .000 \\
\hline Total & 9.200 .000 & 9.200 .000 \\
\hline
\end{tabular}

Sumber :Data Primer (diolah)

\section{- Biaya Tenaga Kerja}

Tenaga kerja yang digunakan dalam industri tempe ini berasal dari keluarga dimana ada 3 orang yang mengerjakan mulai dari proses produksi sampai proses pemasaran, dan ditetapkan setiap orang menerima gaji sebesar Rp. 1.500.000 / orang sehingga dalam setahun biaya tenaga kerja yang digunakan $\mathrm{Rp}$. 54.000 .000

\section{- Biaya Operasi}

Biaya operasi ini terdiri dari biaya pemasaran dan iuran pasar. Dalam memasarkan tempe, industri ini mengeluarkan bahan bakar perharinya sebesar Rp. 32.500 untuk bahan bakar minibus dan untuk iuran pasar Rp. 1.000.000 / bulan untuk tahun 2019 sehingga besar biaya operasi Rp.23.700.000 tahun 2019 sedangkan tahun 2018 berkisar Rp. 22.550 .000

\subsection{Laporan Laba Rugi}

Dalam laporan ini berisikan pendapatan yang diperoleh dan jumlah biaya yang dikeluarkan. Berikut adalah pos-pos yang ada pada laporan laba rugi industri tempe Cempaka

a. Hasil penjualan merupakan jumlah keseluruhan penjualan yang berlangsung selama 1 tahun. Pada tahun 2019 hasil penjulan tempe berkisar Rp. 269.750 .000 
dan pada tahun 2018 sebesar Rp. 269.850.000

b. Harga Pokok Produksi terdiri dari biaya bahan baku, biaya tenaga kerja dan biaya overhead pabrik. Dimana pada tahun 2019 HPP adalah Rp. 175.324.000 dan Rp. 168.750 .000 di tahun 2018

c. Laba kotor merupakan pengurangan dari hasil penjualan dan HPP

d. Biaya operasi merupakan biaya penjualan yang terdiri dari biaya bahan bakar pemasaran dan sewa kios.

e. Laba bersih didapat dari laba kotor dikurangi biaya operasi dimana pada tahun 2019 laba yang diperoleh sebesar Rp. 70.726 .000 dibanding tahun 2018 berkisar Rp. 78.550.000.

Tabel 4 : Laporan Laba/Rugi Tempe Cempaka

\begin{tabular}{|l|c|c|}
\hline & 2018 (Rp) & 2019 (Rp) \\
\hline $\begin{array}{l}\text { Hasil } \\
\text { Penjualan } \\
\text { Tempe }\end{array}$ & 269.850 .000 & 269.750 .000 \\
\hline HPP & $(168.750 .000)$ & $(175.324 .000)$ \\
\hline Laba kotor & 101.100 .000 & 94.426 .000 \\
\hline Biaya Operasi & $(22.550 .000)$ & $(23.700 .000)$ \\
\hline Laba Bersih & 78.550 .000 & 70.726 .000 \\
\hline
\end{tabular}

Sumber : Data Primer (Diolah)

\subsection{Neraca}

Neraca pada usaha tempe cempaka dilaporkan pada akhir tahun. Berikut merupakan neraca pada tahun 2018 dan tahun 2019.

Aktiva :

a. Kas tahun 2018 sebesar Rp. 50.000 .000 dan tahun 2019 menjadi Rp. 52.000 .000

b. Persediaan merupakan jumlah bahan baku dan bahan penolong yang tersisa pada akhir tahun 2018 sebesar Rp. 50.000 dan tahun 2019 sebesar Rp. 75.000

c. Akumulasi penyusutan menggunakan metode garis lurus dan mendapat biaya penyusutan sebesar Rp. 1.200.000/tahun untuk peralatan dan Rp. 5.000.000 / tahun untuk kenderaan

Passiva : a. Utang usaha pada tahun 2018 sebesar Rp. 45.000.000 dan pada tahun 2019 menurun menjadi Rp. 20.000 .000

b. Modal pada neraca merupakan modal akhir yang didapat pada laporan perubahan modal.

Tabel 5 : Neraca Usaha Tempe Cempaka

\begin{tabular}{|l|r|r|}
\hline & 2018 (Rp) & \multicolumn{1}{|c|}{ 2019 (Rp) } \\
\hline $\begin{array}{l}\text { Aktiva } \\
\text { Lancar }\end{array}$ & & \\
\hline Kas & 50.000 .000 & 52.000 .000 \\
\hline Persediaan & 50.000 & 75.000 \\
\hline Total & 50.050 .000 & 52.075 .000 \\
\hline $\begin{array}{l}\text { Aktiva } \\
\text { Tetap }\end{array}$ & & \\
\hline Peralatan & 9.550 .000 & 8.350 .000 \\
\hline $\begin{array}{l}\text { Akm. } \\
\text { Peny. } \\
\text { Peralatan }\end{array}$ & $(1.200 .000)$ & $(1.200 .000)$ \\
\hline Kenderaan & 80.000 .000 & 75.000 .000 \\
\hline $\begin{array}{l}\text { Akm. } \\
\text { Peny. } \\
\text { Kenderaan }\end{array}$ & $(5.000 .000)$ & $(5.000 .000)$ \\
\hline $\begin{array}{l}\text { Total } \\
\text { Aktiva }\end{array}$ & 133.400 .000 & 129.225 .000 \\
\hline Passiva & & \\
\hline $\begin{array}{l}\text { Hutang } \\
\text { Usaha }\end{array}$ & 45.000 .000 & 20.000 .000 \\
\hline Modal & 88.400 .000 & 109.225 .000 \\
\hline $\begin{array}{l}\text { Total } \\
\text { passive }\end{array}$ & 133.400 .000 & 129.225 .000 \\
\hline
\end{tabular}

Sumber : Data Primer (diolah)

\subsection{Laporan Perubahan Modal}

Modal awal yang digunakan usaha Tempe Cempaka sebesar Rp. 50.000 .000 dan pengambilan uang untuk keperluan pribadi $\mathrm{Rp}$. 40.150.000 untuk tahun 2018 dan Rp. 49.901.000 untuk tahun 2019.

Tabel 6 : Laporan Perubahan Modal Usaha Tempe Cempaka :

\begin{tabular}{|l|c|c|}
\hline & 2018 (Rp) & 2019 (Rp) \\
\hline Modal awal & 50.000 .000 & 88.400 .000 \\
\hline Laba Bersih & 78.550 .000 & 70.726 .000 \\
\hline $\begin{array}{l}\text { Penambahan } \\
\text { modal }\end{array}$ & 128.550 .000 & 159.126 .000 \\
\hline
\end{tabular}




\begin{tabular}{|l|r|r|}
\hline Prive & $(40.150 .000)$ & $(49.901 .000)$ \\
\hline Modal Akhir & 88.400 .000 & 109.225 .000 \\
\hline
\end{tabular}

\subsection{Rasio Keuangan}

Dari pengukuran rasio keuangan dapat dilihat kinerja dan posisi perusahaan yang terlihat pada tabel berikut :

Tabel 7 : Hasil Pengukuran Rasio Keuangan tahun 2018 dan tahun 2019

\begin{tabular}{|l|c|l|c|l|}
\hline Jenis Rasio & $\mathbf{2 0 1 8}$ & Kriteria & $\mathbf{2 0 1 9}$ & Kriteria \\
\hline Likuiditas & & & & \\
\hline CR & 1,11 & $\begin{array}{l}\text { Sangat } \\
\text { tidak baik }\end{array}$ & 2,6 & Baik \\
\hline QR & 1,11 & $\begin{array}{l}\text { Tidak } \\
\text { baik }\end{array}$ & 2,6 & Baik \\
\hline Solvabilitas & & & & \\
\hline DR & $33,78 \%$ & Baik & $15,48 \%$ & Baik \\
\hline Profitabilitas & & & $35,01 \%$ & Baik \\
\hline GPM & $37,47 \%$ & Baik & $26,22 \%$ & Baik \\
\hline NPM & $29,11 \%$ & Baik & $54,73 \%$ & Baik \\
\hline ROI & $58,88 \%$ & Baik & $64,75 \%$ & Baik \\
\hline ROE & $88,85 \%$ & Baik & & \\
\hline
\end{tabular}

Sumber : Data Primer (diolah)

Dari hasil rasio keuangan ini akan terlihat kinerja keuangan dalam usaha ini yaitu :

- Rasio Likuiditas

Berdasarkan hasil pengukuran rasio likuiditas pada tahun 2018 adalah 1,11 x artinya jumlah aktiva lancar sebanyak 1,11 rupiah dimana dapat ditafsirkan setiap 1 rupiah utang lancar dijamin oleh 1,11 rupiah harta lancar. Pada tahun 2019 usaha Tempe Cempaka mengalami peningkatan menjadi 2,60 disebabkan hutang telah berkurang hal ini menunjukkan usaha Tempe Cempaka mampu membayar kewajibannya dengan baik.

- Rasio Solvabilitas

Dari hasil pengukuran DR pada tahun 2018 adalah 33,78\% menunjukkan 33,78\% pendanaan perusahaan dibiayai dengan hutang. Dan pada tahun 2019 menurun menjadi $15,48 \%$ karena sebagian hutang telah dibayar. Menyebabkan pendanaan usaha dengan hutang sedikit, sehingga perusahaan dapat dengan mudah mengajukan pinjaman.

- Rasio Profitabilitas

GPM menunjukkan hasil analisis pada tahun 2018 sebesar 37,47\% dan tahun 2019 menurun menjadi $35,01 \%$. Penurunan disebabkan pengurangan jumlah produksi, namun hal ini tidak mempengaruhi kinerja keuangan usaha dalam memperoleh laba sehingga dinyatakan baik.

NPM menunjukkan margin laba perusahaan pada tahun 2018 sebesar $29,16 \%$ dan tahun 2019 menurun menjadi $26,22 \%$ akibat dari bertambahnya penggunaan bahan baku dan bahan penolong. Namun hal ini tidak mempengaruhi kinerja usaha dalam memperoleh laba bersih sehingga kinerja keuangan tahun 2018 dan 2019 dinyatakan baik.

ROI menunjukkan produktivitas dari seluruh dana perusahaan. Perhitungan ROI tahun 2018 sebesar 58,88\% artinya hasil pengembalian aktiva berkurang sebesar $58,88 \%$ dan ini menunjukkan kemampuan manajemen untuk memperoleh ROI. Dan tahun 2019 menurun menjadi 54,73\%. Namun dengan margin laba tahun 2018 dan 2019 berada pada posisi baik, sehingga tidak mempengaruhi usaha ini.

ROE menunjukkan efisiensi penggunaan modal sendiri, semakin tinggi rasio berarti posisi keuangan pemilik industri semakin kuat. Perhitungan ROE tahun 2018 menunjukkan bahwa tingkat pengembalian diperoleh sebesar 88,86\% dan tahun 2019 menurun menjadi $64,75 \%$ namun hal tersebut tidak mempengaruhi kinerja keuangan usaha ini, karena berada pada posisi baik.

\section{KESIMPULAN}

Dari hasil penelitian ini untuk mengetahui kinerja keuangan industri Tempe Cempaka tahun 2018 - 2019 dengan menggunakan analisis rasio keuangan, yaitu rasio likuiditas, rasio solvabilitas dan rasio profitabilitas dapat 
disimpulkan bahawa kinerja keuangan usaha Tempe Cempaka dinyatakan baik. Namun walaupun cukup baik penulis juga memberikan saran yang ditawarkan yaitu :

- Untuk pemilik usaha, setelah diketahui kinerja keuangan dari usaha ini baik, dapat segera mengajukan pinjaman dana KUR untuk lebih mengembangkan produksi Tempe Cempaka dan dapat melakukan perluasan pemasaran produk ke daerah lain selain kota Pematangsiantar dan Kabupaten Simalungun.

- Untuk masyarakat, usaha ini dapat menjadi contoh bagi masyarakat untuk mencoba membuka usaha tempe karena proses produksinya tidak susah dan pemasarannya pasti lancar apalagi tempe merupakan makanan tradisi masyarakat Indonesia yang mempunyai nilai gizi yang tinggi.

\section{REFERENSI}

[1] Susianto and R. Ramayulis, Fakta Ajaib Khasiat Tempe. Jakarta: Penebar Plus, 2013.

[2] S. S. Harahap, Analisis Kritis atas Laporan Keuangan. Jakarta: PT. Raja Grafindo Persada, 2007.

[3] S. Munawir, Analisa Keuangan. Yogyakarta: Liberty, 2010.

[4] L. Syamsudin, Manajemen Keuangan Perusahaan: Konsep Aplikasi Dalam Perencanaan, Pengawasan, dan Proses Pengambilan Keputusan. Jakarta: PT. Raja Grafindo Persada.

[5] L. Purwono and Heni Purnawanti, Budidaya 8 Jenis Tanaman Pangan Unggul. Jakarta: Penerbit Swadaya, 2007.

[6] Mamduh. M. Hanafi. 2003. Analisis Laporan Keuangan, UPP AMK YKPN, Yogyakarta. Posma Pratama

[7] Yosafat. 2015. "Analisis Kinerja Keuangan Berdasarkan Rasio Profitabilitas Pada Rumah Sakit Bakti Timah Pangkal Pinang”. Jurnal Akuntansi Bisnis \& Keuangan (Jabk), Vol 1, ISSN 2355-9047

[8] Rahman Pura. 2013. Pengantar Akuntansi 1 Pendekatan Siklus
Akuntansi, Jakarta: Penerbit Erlangga.

[9] Ridwan S. Dan Inge Barlian. 2003. Manajemen Keuangan 2 Edisi keempat. Literata Lintas Media Jendela Ilmu Dunia, Jakarta

[10] Sofyan Syafri Harahap. 2010. Analisis Kritis Atas Laporan Keuangan. Jakarta: Rajawali Pers 